\title{
溶湯法ポーラスアルミニウムの気孔形態と 圧縮強度に及ぼす発泡条件の影響
}

\author{
瀆 田 猛 1 西 誠 治 ${ }^{1}$
${ }^{1}$ 株式会社神戸製鋼所神戸総合技術研究所
2 神鋼鋼線工業株式会社泉佐野事業所 \\ 3 名古屋大学大学院工学研究科
}

J. Japan Inst. Metals, Vol. 72, No. 10 (2008), pp. 825-831

(C) 2008 The Japan Institute of Metals

\section{Effect of Foaming Condition in the Melt on Cell Structure and Compression Strength of Porous Aluminum}

Takeshi Hamada ${ }^{1}$, Seiji Nishi ${ }^{1}$, Tetsuji Miyoshi ${ }^{2}$ and Naoyuki Kanetake ${ }^{3}$

${ }^{1}$ Kobe Corporate Research Laboratory, Kobe Steel, Ltd., Kobe 651-2271

${ }^{2}$ Shinko Wire Company, Izumisano 598-0071

${ }^{3}$ Graduate School of Engineering, Nagoya University, Nagoya 464-8603

Recently, aluminum foams with more homogeneous pores are expected from the improvement of compression strength reliability. In this research, for the closed cell $\mathrm{Al}$ foams which are fabricated by adding foaming agent to molten aluminum (direct aluminum foaming in melt), the effect of pore control regarding viscosity, cooling rate and foaming agent size on the uniaxial static compression strength was examined.

As a result, it is possible to make small and homogeneous pores by increase in viscosity, improvement in cooling rate and using a smaller foaming agent. However, Al foam with smaller a foaming agent became higher density as well as decreasing the pore size.

The increment in the density of $\mathrm{Al}$ foam depends on the cell structure (thick cell walls and small pores). This is, the density increases with decreasing average pore diameter.

Compression strength (plateau stress) of $\mathrm{Al}$ foams with small and homogeneous pores was improved. When the compression strength of Al foams is shown in relation to density and plateau stress, plateau stress was about the square of the increase in density.

(Received May 27, 2008; Accepted July 10, 2008)

Keywords: foam, density, pore size, cell structure, static compression stress, plateau region, plateau stress

\section{1. 緒言}

内部に無数の独立気泡が分散したクローズドセル構造の ポーラスアルミニウムは, 超軽量でありながら高い比剛性を 有し ${ }^{1)}$, さらに遮音 - 吸音性, 制振性, 断熱性や切削加工性 などにも優れていることから, 防 (吸)音建材や防護壁, 工作 機械部材2) などの充填補剛材などに使われている. 最近で は，アルミニウムハニカムと比べて強度に等方性があり, 高 エネルギー吸收性1)を示すことが知られ, 自動車などの車 両1,3), 航空機3)などの軽量化材料としての適用が期待されて いる.このポーラスアルミニウムを機械的特性が要求される 構造部材として工業利用を展開するためには, 気孔形態の均 質・微細化やこれらの制御による強度の安定化が望まれてい る.

一方，クローズドセル構造のポーラスアルミニウムの製造 方法には, アルミニウム溶湯に発泡助剂を添加した後に凝固 する方法 ${ }^{4}$ (以下, 溶湯発泡法と呼ぶ) やアルミニウム粉末に
発泡助剤を混合して固化したプリカーサを加熱して発泡する 方法，アルミニウム溶湯中にガスを吹込み，そのまま凝固す る方法，粉末を原料として作製した中空金属球を充填成形す る方法など1)がある. その中で, 溶湯発泡法は気孔形態が比 較的均質で大型サイズのブロックを短時間に低コストで得ら れる方法として, 工業利用の更なる展開が期待される. 溶湯 発泡法では, アルミニウム溶湯の粘性を増加させることが気 孔の生成には重要5)である. そして, 急速増粘剤として金属 カルシウム $(\mathrm{Ca})$ を添加すると粘性が増加して気孔径が小さ くなることが確認され ${ }^{6-8)}$ 気孔径や比重と圧縮強度との関係 についても報告9-11)されている. しかし, 広範囲の $\mathrm{Ca}$ 添加 量に対する粘性の変化や気孔形態および圧縮変形特性への影 響を定量的に検討した報告はされていない, さらに, 冷却速 度や発泡助剂の粒径など粘性以外のプロセス因子と気孔形態 および圧縮特性との関係を検討した報告も見当たらない。そ こで, 本研究では溶湯発泡法において, 従来より広範囲の Ca 添加量による粘性の変化を始め, 発泡後の冷却速度, 発 泡助剤粒径などのプロセス因子と気孔形態の変化について検 
討した。そして，これらの因子による比重や気孔形態の変化 が圧縮強度および圧縮応力ーひずみ曲線に及ぼす影響を系統 的に解明した。

\section{2. 実 験 方 法}

Fig. 1 に溶湯発泡法によるポーラスアルミニウムの製造方 法を示す．約 $33 \mathrm{~kg}$ の 99\%工業用純アルミニウム溶湯を幅 $310 \times$ 長さ $630 \times$ 高さ $630 \mathrm{~mm}$ の鋳型内で溶解 $(953 \mathrm{~K})$ し, アルミニウムより酸素との親和力の強い金属カルシウム(純 度 99\%)を添加し，覺拌 (750 rpm) することで増粘6,7)する. 増粘は，発泡助剤より発生した気泡の結合やガスの消出を抑 制するため行わなければならない処理である. 従来, この粘 性を増すために合金 $(\mathrm{Ca}, \mathrm{Mg}$ など高酸素親和性元素) 添加 法5)，微粒子 $\left(\mathrm{SiC}, \mathrm{Si}_{3} \mathrm{~N}_{4}, \mathrm{Al}_{2} \mathrm{O}_{3}\right.$ など) 混合法 $\left.{ }^{12}\right)$ などが行われ ているが，いずれも溶湯を酸化させ，酸化物を均一分解させ ることによって溶湯の粘性を増加させる方法である. 次に, アルミニウム増粘溶湯中 $(943 \mathrm{~K})$ に発泡助剂 $\left(\mathrm{TiH}_{2}\right)$ を添加・ 攪拌 (100 秒)することで発泡膨張させ, 強制空冷してポーラ スアルミニウムを作製する.

増粘剂 $(\mathrm{Ca})$ の添加量を 1.5 mass \% , 増粘攪拌時間を 5 分，発泡助剂 $\left(\mathrm{TiH}_{2}\right)$ の粒子径を $45 \mu \mathrm{m}$ 以下，添加量を 1.5 mass \%の条件で作製したポーラスアルミニウムを標準供試 材として，比重の異なる複数個の供試材を作製した。この標 準供試材に対して, 気孔形態や圧縮特性への各条件の影響を 検討するために，増粘剤添加量を $0.5 \sim 5.0$ mass \% ，増粘攪 拌時間を $1 \sim 20$ 分，発泡助剤 $\left(\mathrm{TiH}_{2}\right)$ の粒子径を $20 \mu \mathrm{m}$ 以下 と個別に条件を変化した供試材，および発泡膨張後に強制水 冷で凝固させた供試材を作製した。これら個別の条件を変え る場合，他の条件は標準供試材と同じ条件とした。

鋳型内で凝固後のポーラスアルミニウムの中央の高さ方向 に，上，中，下部の各場合から $50 \mathrm{~mm}$ 角の立方体試験片を 採取して, 比重の計測, 気孔分布の計測, 圧縮試験を行っ た。比重の計測は, 電子天秤 (精度 $0.1 \mathrm{mg}$ )による試験片重 量測定とノギスによる試験片寸法測定から求めた。また，気 孔分布の計測には，試験片の試料観察断面 $\left(50 \times 50 \mathrm{~mm}^{2}\right)$ を \# 1,500 まで研磨して印画転写した。転写画像データを二值 化処理して画像解析し, 気孔径(面積相当円直径)の分布と平 均気孔径を求めた。 画像処理上の解析精度の観点から気孔径 $1 \mathrm{~mm}$ 未満を除外した。なお，二次元観察であるため実際よ りも平均気孔径は小さく，分布の範囲が広くなると思われる

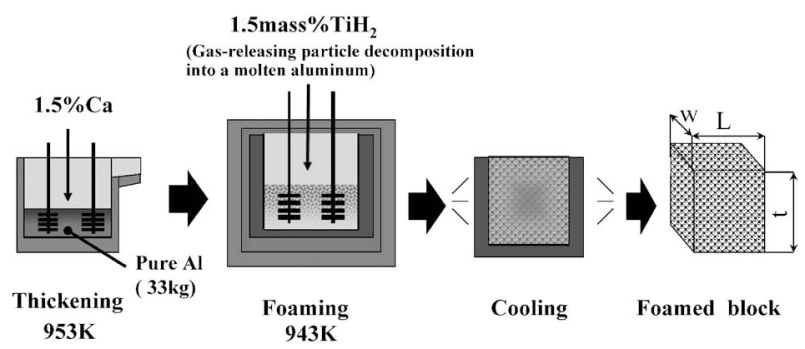

Fig. 1 Manufacturing process of an experimental Al foam. (Experimental block size: $310 \mathrm{~W} \times 630 \mathrm{~L} \times 630 \mathrm{t} \mathrm{mm}$ )
が，本論文ではこれらの気孔形態で考察した．圧縮試験には 気孔分布計測後の試験片を用い，インストロン社製万能試験 機，圧縮速度 $5 \mathrm{~mm} / \mathrm{min}$ で行い，ロードセルおよびクロス ヘッド変位量から荷重-変位曲線を求めた。この荷重一変位曲 線から, 荷重を初期の試験片断面積, 変位を初期の試験片高 さで除して圧縮応力ーひずみ曲線にした.

\section{3. 実 験 結 果 \\ 3.1 標準供試材の圧縮特性}

Fig. 2 にいくつかの標準供試材の圧縮応力ーひずみ曲線と 各試料の比重を示す．本論文では，降伏以降のひずみの増加 に対して応力の変化が少なく, ほぼ一定の勾配で応力が変化 する部分をプラトー領域とし，全試料の圧縮試験結果を統一 的に比較するために，20 $30 \%$ 変形時の圧縮応力の平均値 をプラトー応力と定義した．Fig. 2 より，広く知られてい る1)ように，比重の増加に伴ってプラト一領域は短くなり， プラト一応力が上昇することがわかる．また，低比重試料の プラトー応力はほとんど一定であるが，高比重試料ではプラ トー領域でも圧縮応力が徐々に増加する傾向となる. Fig. 3 に 15 個の標準供試材の比重と圧縮試験のプラトー応力およ び平均気孔径，気孔分布の標準偏差との関係を示す。同図よ り，比重の増加に伴って平均気孔径が小さくなり，気孔分布 の標準偏差も同様な傾向で変化をしている，一方，プラトー 応力は比重の増加に伴って単調に上昇することがわかる。

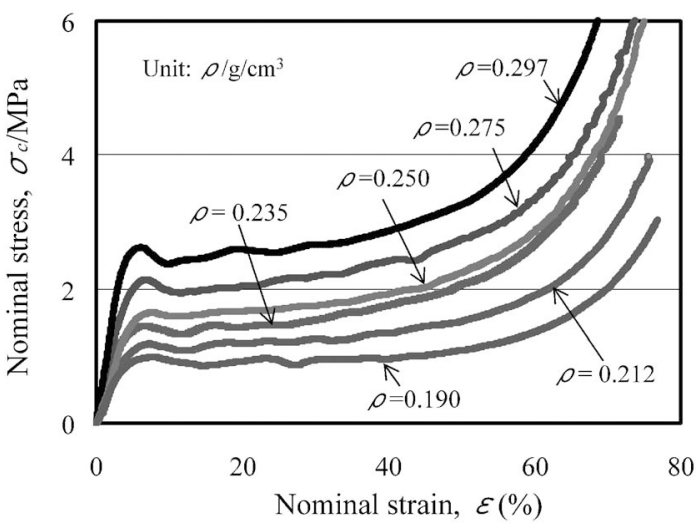

Fig. 2 Compressive stress-strain curves of several standard Al foams.

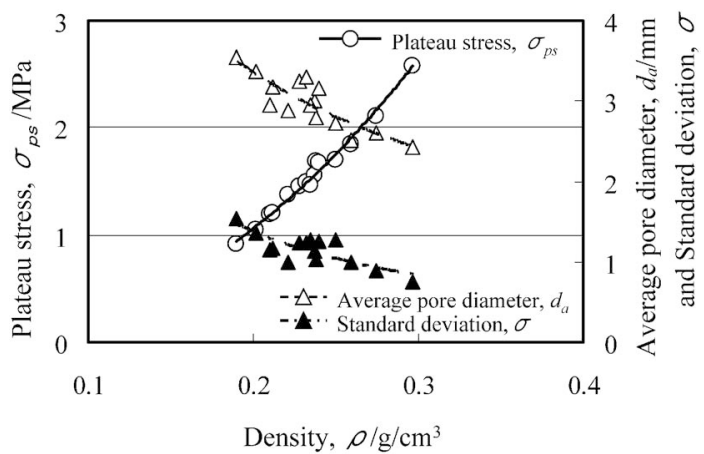

Fig. 3 Relation between density and plateau stress of standard Al foams. 


\section{2 増粘時間および増粘剤添加量の影響}

Fig. 4 に，異なる増粘剂 $(\mathrm{Ca})$ 添加量による増粘攪汼時間 と増粘攪汼トルクとの関係を示す。増粘攪汼トルクは攪汼翼 の軸に取り付けたトルク計での測定值である. Ca 添加量が 多く，増粘攪拌時間が長いほど増粘攪拌トルクが大きくな り，見掛け上の溶湯粘性が高くなることがわかる ${ }^{8-10)}$. Fig. 5 に 1.5 mass \% Ca 添加における増粘攪拌時間を変えた供試 材の鋳型上, 中, 下 $(\mathrm{TOP}, \mathrm{CEN}, \mathrm{BOT})$ に打汀平均気孔径 および気孔分布の標準偏差を示す。同図より，鋳型下部で気 孔径が多少小さく，いずれの場所も増粘攪汼の初期には攪汼 時間が長いとわずかではあるが，平均気孔径および気孔分布 の標準偏差は小さくなり 5 分程度でほぼ一定となることが わかる. Fig. 4 では, 溶湯粘性は攪汼時間 15 分程度まで上 昇するが，粘性上昇の気孔径への影響はそれほど顕著ではな いと思われる. Fig. 6 に Fig. 5 の増粘攪拌時間を变更した 供試材の鋳型中央部試験片の圧縮応力ーひずみ曲線を，同程 度の比重の標準供試材と共に示す. 増粘攪拌時間によってプ ラトー応力が異なるが，これは各試料の比重の差によるもの で, 同比重の標準供試材との差は少ないことから, 増粘攪汼 時間の影響は小さいことがわかる.

Fig. 7 に増粘剤 $(\mathrm{Ca})$ の添加量を $0.5 \sim 5.0$ mass\% と変化し た供試材の鋳型上, 中, 下部 (TOP, CEN, BOT)に抢ける平 均気孔径および気孔分布の標準偏差を示す. 同図の $0.5 \sim 1.5$ mass \% Ca では少量の増粘剤添加の効果を確実にするため増 粘攪汼時間を 20 分とし， $2.5 \sim 5.0$ mass $\% \mathrm{Ca}$ では攪拌機の

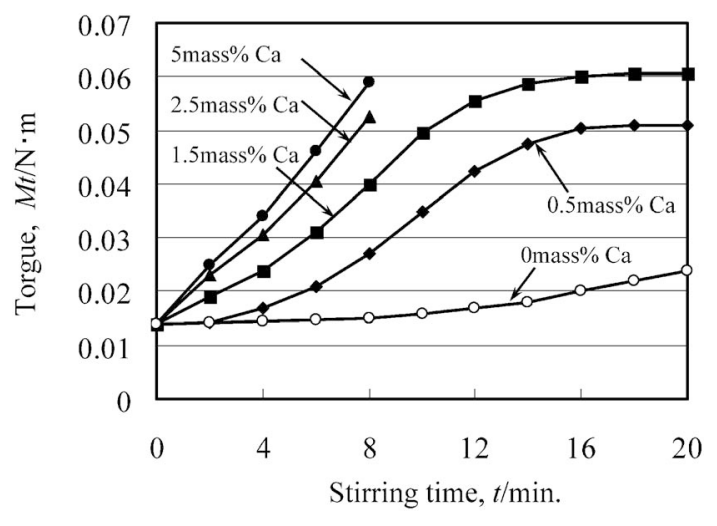

Fig. 4 Relationship between stirring time and torque.

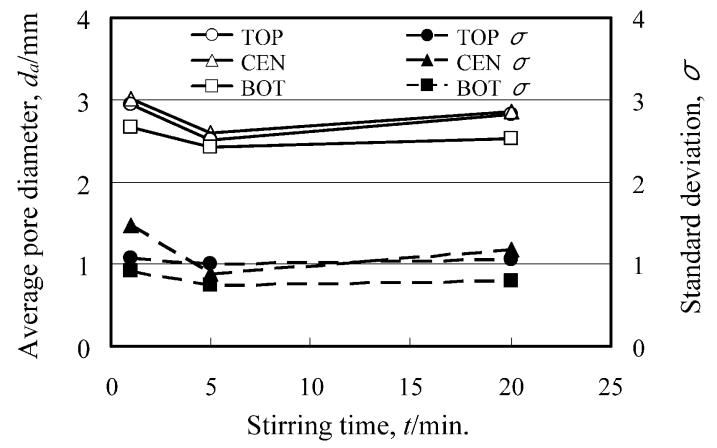

Fig. 5 Relationship between stirring time and pore size under 1.5 mass \% Ca content.
負担減のため増粘攪拌時間を 5 分とした。同図より, Ca 添 加量が多いほど, 平均気孔径抢よび気孔分布の標準偏差は小 さくなり， 2.5 mass\%以上でこれらはほぼ一定となることが わかる. また, Ca 添加量が少ないと鋳型内の場所による気 孔径の差が大きいが, 1.5 mass \%以上の供試材で上, 中, 下 部の平均気孔径のばらつきは $20 \%$ 以内となる. Fig. 8 は 1.0 と 2.5 mass\%添加の供試材断面の気孔径分布を示す画像で あり，紙面下方が重力作用方向である. 1.0\%と 2.5\%の気孔 径の差や $1.0 \%$ における上, 中, 下部の気孔径の差が明確で ある. 1.0\%の気孔径分布を示す画像では, 上・中部で気孔

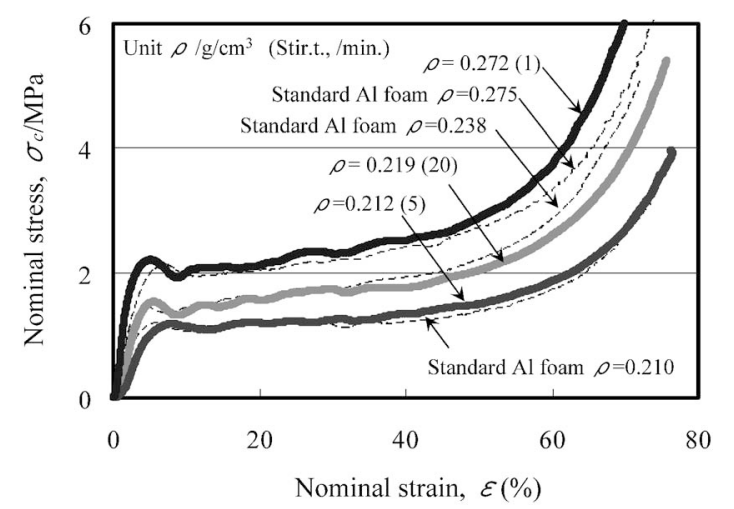

Fig. 6 Effect of stirring time on compressive stress-strain curves under 1.5 mass $\%$ Ca content.

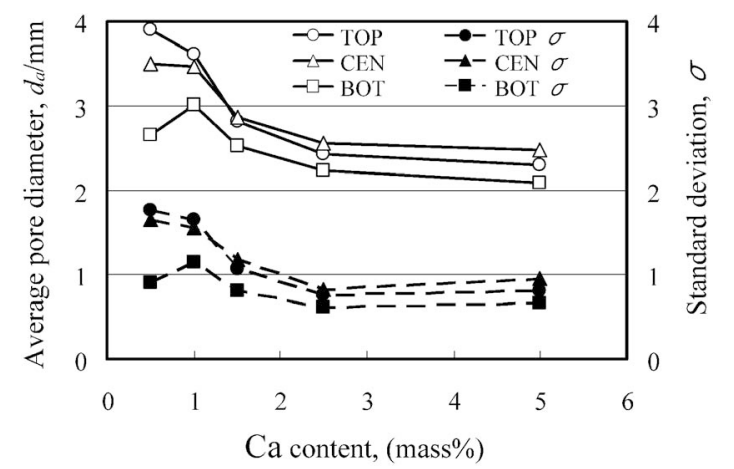

Fig. 7 Relationship between Calcium content and pore size.

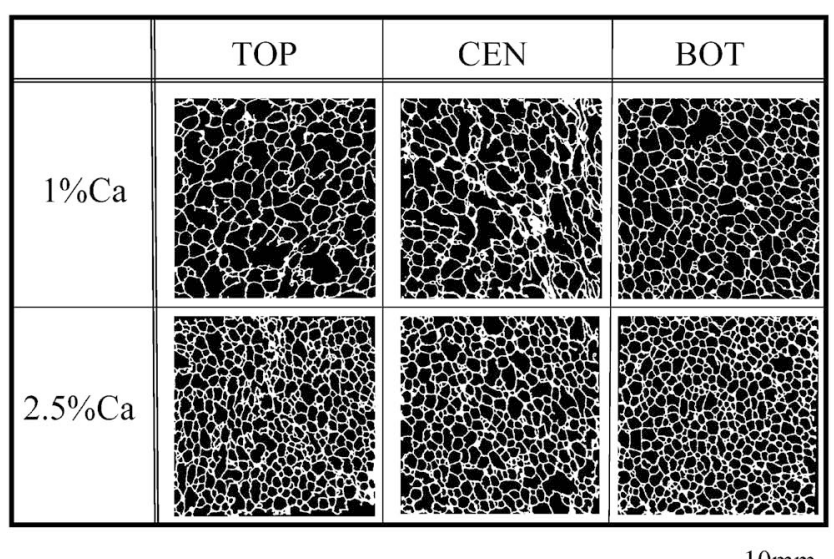

Fig. 8 Effect of $\mathrm{Ca}$ content on cell structure of several $\mathrm{Al}$ foams. 
の合体やセル壁の崩壊による不規則形状の大きな気孔が観察 され，そのために平均気孔径が大きく，気孔径分布の標準偏 差も大きくなったことがわかる．粘性が低い(増粘攪汼時間 が短く, 増粘剤添加量が少ない) 他の供試材でも同様の気孔 形態が観察され, 粘性の低い供試材の上部ほど発泡助剤のガ ス圧を気孔内に保持しておくことができないためと考えられ る. また, 発泡助剤 $\left(\mathrm{TiH}_{2}\right)$ の水素ガス解離はアルミニウム 溶湯への投入直後に急速に進み, その後は少ない解離力゙ス量 が長時間続くことが報告されている11,13)。従って供試材下部 (BOT)では, 上・中部である程度水素ガスを解離した発泡 助剂が下部に降下して, 発泡ガスの逃げられない静水圧状態 下でゆっくりと発泡することから, 気孔の合体なども少なく 平均気孔径が小さく均質な気孔となり，粘性(増粘攪拌時間 や増粘剂添加量)の影響が少なかったものと思われる.

Fig. 9 に, Fig. 7 で示した増粘剤添加量が標準供試材 $(1.5 \%)$ よりも少ない試験片 $(0.5 \%, 1.0 \%)$ の圧縮応力ーひず み曲線を示す。同図中には，比重がほぼ同等の標準供試材の 圧縮応力ーひずみ曲線を併記した。同図より, 増粘剤添加量 が少ない試験片の圧縮強度は同比重の標準供試材よりもわず かではあるが低いことがわかる。一方，Fig. 10 は増粘剤添 加量が標準供試材よりも多い試験片 $(2.5 \%, 5.0 \%)$ の圧縮応 力ーひずみ曲線を, 比重がほぼ同等の標準供試材の圧縮応力一

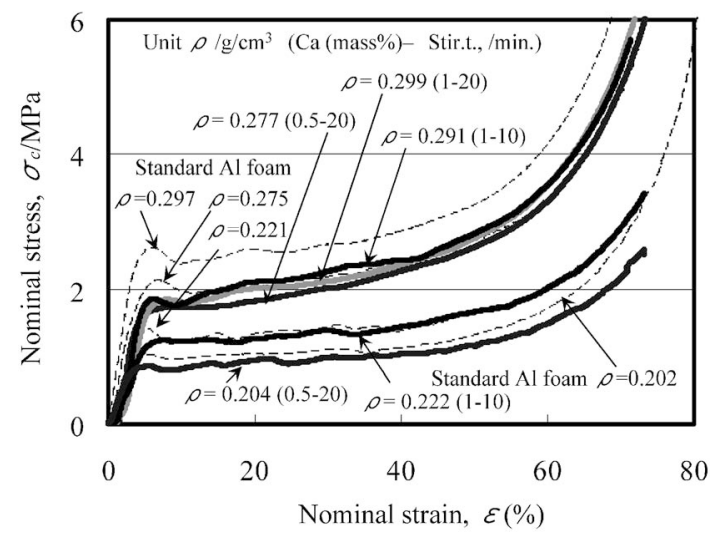

Fig. 9 Effect of low $\mathrm{Ca}$ content $\mathrm{Al}$ foams on compressive stress-strain curves.

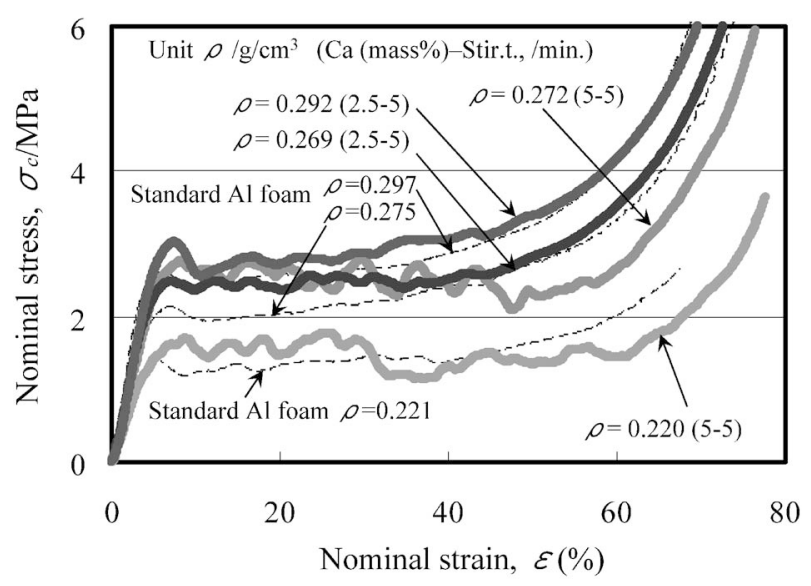

Fig. 10 Effect of high $\mathrm{Ca}$ content $\mathrm{Al}$ foams on compressive stress-strain curves.
ひずみ曲線と併記した。増粘剤添加量が多い試験片はプラ トー領域の圧縮強度が同比重の標準供試材よりもいずれも高 いことがわかる。 また， $5.0 \% \mathrm{Ca}$ 添加の試験片ではプラトー 領域での応力変動が標準供試材に比べて大きく, プラト一領 域が長くなっていることがわかる．これは圧縮過程の変形挙 動の違いによるもので， $2.5 \% \mathrm{Ca}$ 以下の添加の試験片は，セ 儿壁の延性的な屈曲による圧縮変形であったが， $5.0 \%$ 添加 の試験片では試験片外表面でセル壁の脆性的な破壊を伴う圧 縮変形をした。Fig. 11 に標準供試材 $(1.5 \% \mathrm{Ca})$ と $2.5 \% \mathrm{Ca}$ 添加材, $5.0 \% \mathrm{Ca}$ 添加材の SEM 観察結果を示す. EDX 分 析から Fig. 11 の薄灰色部は $\mathrm{Ca}-\mathrm{Ti}$ 化合物であり, $\mathrm{Ca}$ 添加 量が増すと生成化合物も増え, $5.0 \% \mathrm{Ca}$ 添加材になると化合 物が凝集して存在することがわかる.このために Ca 添加量 の多い試料ではセル壁の延性が低下したものと思われる.

以上より, 増粘剤添加量によって気孔形態を制御して圧縮 特性をある程度制御することが可能であるが，添加量が少な いと鋳型内上・下位置での不均質が大きくなり, 添加量が多 いと変形特性が脆性的になり, さらに粘性の増加に伴う攪拌 操作など製造プロセスでの課題が残る. 以下の実験結果は, 増粘剤添加量 $1.5 \%$ で, 鋳型内の場所による不均質は少ない ので，全て中央部の結果を示す.

\section{3 冷却速度の影響}

Fig. 12 に, ほぼ同比重の標準供試材 (空冷) および水冷し

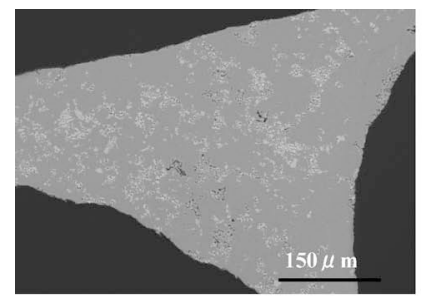

a) Standard Al foam

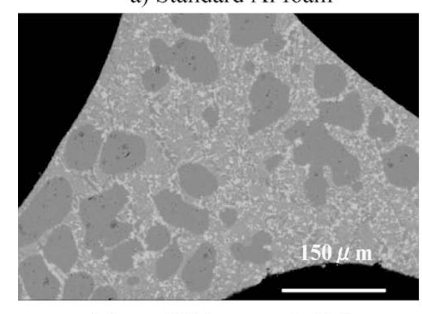

c) 5 mass $\%$ Ca content $\mathrm{Al}$ foam

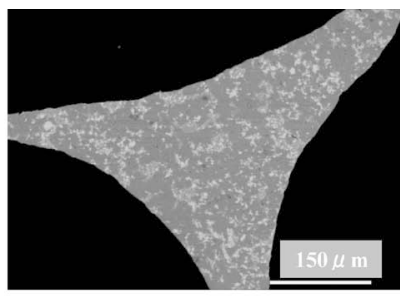

b) 2.5 mass $\% \mathrm{Ca}$ content $\mathrm{Al}$ foam
Fig. 11 SEM micrograph of the different $\mathrm{Ca}$ content $\mathrm{Al}$ foams.

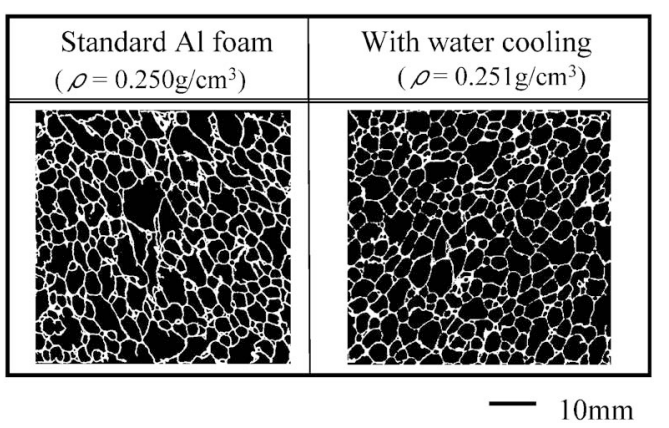

Fig. 12 Cell structure of the $\mathrm{Al}$ foam with water cooling. 
た供試材の気孔径分布を示す画像を，Fig. 13 に冷却方法の 違いによるほぼ同比重の標準供試材の気孔径分布計測結果を 示す. Fig. 12 の紙面下方は重力作用方向である. 同図には 平均気孔径 $\left(d_{\mathrm{a}}\right)$ と気孔分布の標準偏差 $(\boldsymbol{\sigma})$ を併記した。な お, 鋳塊中心に取付けた熱電対による測定から固液共存域 $(901 \sim 928 \mathrm{~K})$ での冷却速度は, 空冷では $0.1 \mathrm{~K} / \mathrm{s}$, 水冷では $0.5 \mathrm{~K} / \mathrm{s}$ 程度であった. 水冷材は空冷材に比べて平均気孔径 が小さく，大きな気孔が少なくなることがわかる．すなわ ち, 発泡攪拌後の冷却速度を上げることによって, 気孔の遅 延成長が抑制され，気孔径が小さく均質化されたものと思わ れる.

Fig. 14 に水冷材の圧縮応力ーひずみ曲線をほぼ同比重の標 準供試材 (空冷材)の曲線と比較して示す. 冷却速度の向上に よって圧縮応力が上昇することがわかる. また, プラト一領 域での応力変動は少なく, プラト一領域長さも標準供試材と 変わらず, 水冷材も空冷材と同様に, セル壁の延性的な屈曲 による圧縮変形をしていた。

Fig. 15 は, Fig. 6，9，10，14の各試験片の圧縮応力-ひず み曲線におけるプラトー応力を各試験片の比重に対して整理 したものである. 各プロット点に添えた数字は $\mathrm{Ca}$ 添加量と 増粘攪拌時間を示し, WC は水冷材を示している. また, 各 プロット点は標準供試材 $(1.5 \%, 5 \mathrm{~min})$ より粘性の低いもの と高いものに記号を分けており, 図中の実線は Fig. 3 に示 した標準供試材の関係を示している. 粘性が高い供試材およ

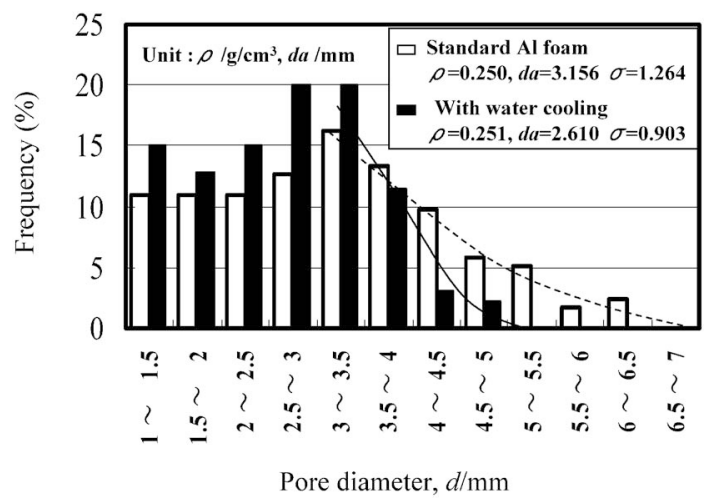

Fig. 13 Distribution of pore size in Al foams with different cooling rates.

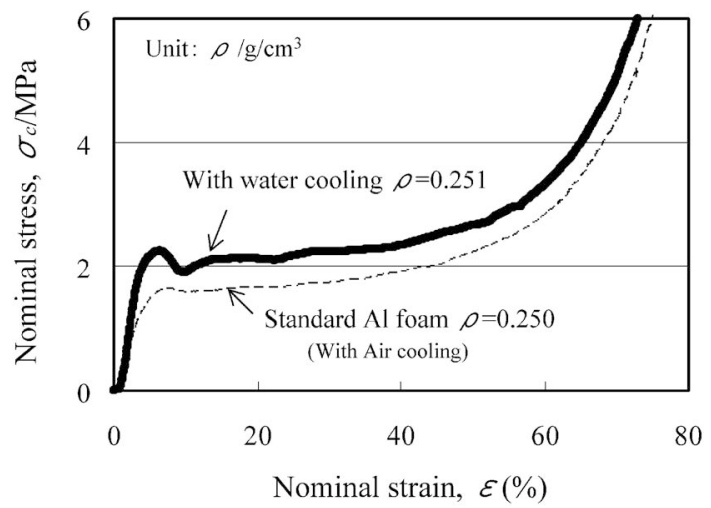

Fig. 14 Compressive stress-strain curves of $\mathrm{Al}$ foams with different cooling rates.
び水冷材は標準供試材と比べて約 20\%向上し，アルミニウ 么溶湯の粘性が不足すると, プラト一応力は標準供試材と比 べて約 15\%低下することがわかる. Fig. 7, 8, 12, 13 から， 粘性が低い条件で作製した試料は, 気孔径が大きく不均質に なるため, 圧縮試験時の試料内の変形が局所的に進むことが 予想され, 試料全体の平均応力 (圧縮応力の測定值)が低下す る結果となる. 逆に, 粘性や冷却速度の増大によって気泡の 成長を抑えて均質小粒径化された試験では, 局所変形が抑制 されてプラトー応力が向上したと思われる.

\section{4 発泡助剤粒径の影響}

Fig. 16 に $45 \mu \mathrm{m}$ 以下の $\mathrm{TiH}_{2}$ を用いた標準供試材と 20 $\mu \mathrm{m}$ 以下の $\mathrm{TiH}_{2}$ を用いた小粒径発泡材の気孔径分布画像と セル壁の拡大写真を示す. 小粒径発泡材の気孔サイズは明ら かに減少すると共に，セル壁が厚くなり，セル壁内に小さな 気孔が存在することがわかる. Fig. 17 に標準供試材と 2 種 類の比重の小粒径発泡材の気孔径分布の計測結果を示す. 小 粒径発泡材は標準供試材とほぼ同量の発泡助剤を添加したに もかかわらず，比重が大きく(気孔率が低く)なり，気孔径と

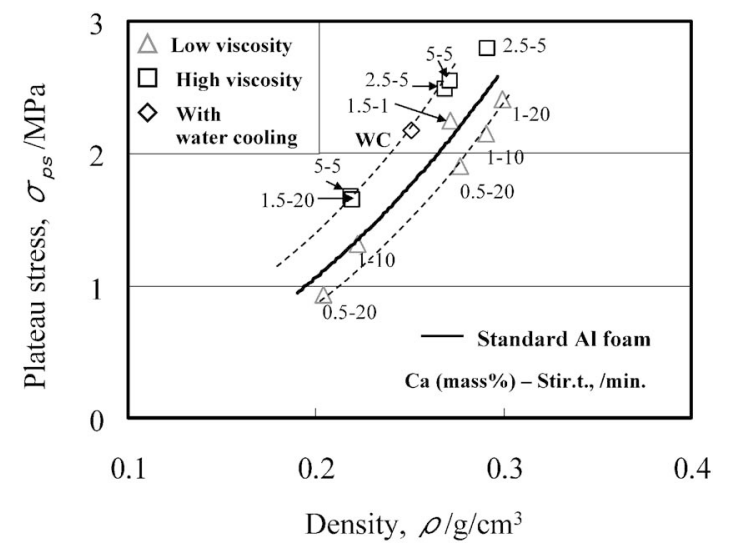

Fig. 15 Relation between density and plateau stress of $\mathrm{Al}$ foams.

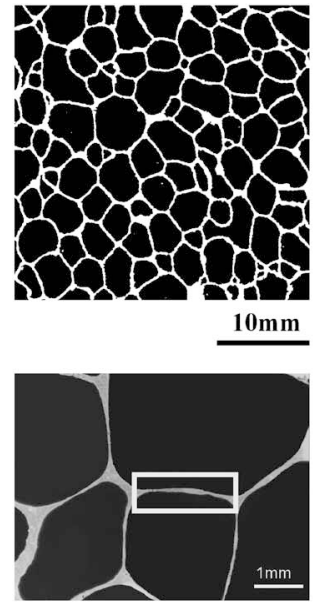

(a) Standard Al foam $\left(\rho=0.297 \mathrm{~g} / \mathrm{cm}^{3}\right)$

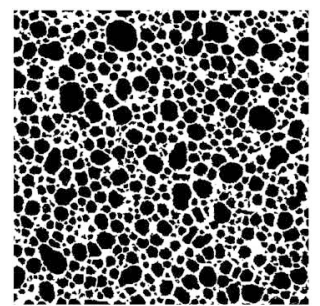

$10 \mathrm{~mm}$

(b) $\mathrm{Al}$ foam with smaller foaming agent $\left(\rho=0.636 \mathrm{~g} / \mathrm{cm}^{3}\right)$

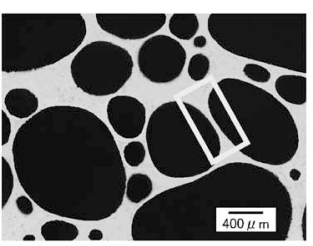

Fig. 16 Cell structure of $\mathrm{Al}$ foams with different sizes of foaming agent. 


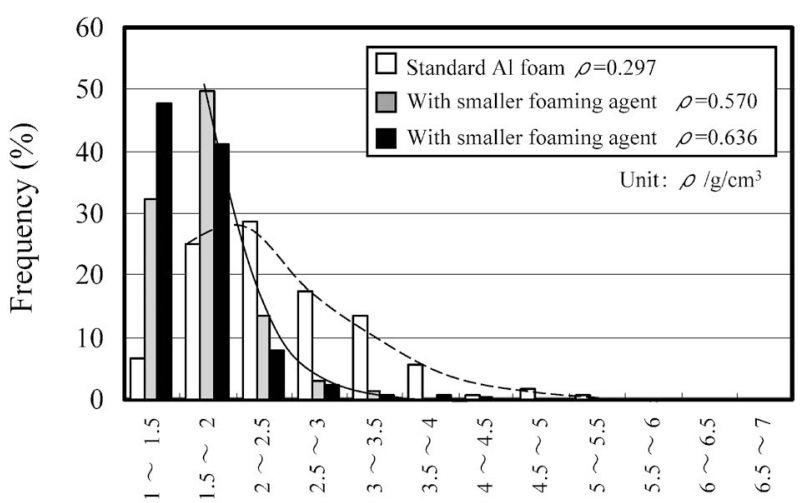

Pore diameter, $d / \mathrm{mm}$

Fig. 17 Distribution of pore size in $\mathrm{Al}$ foams with different sizes of foaming agent.

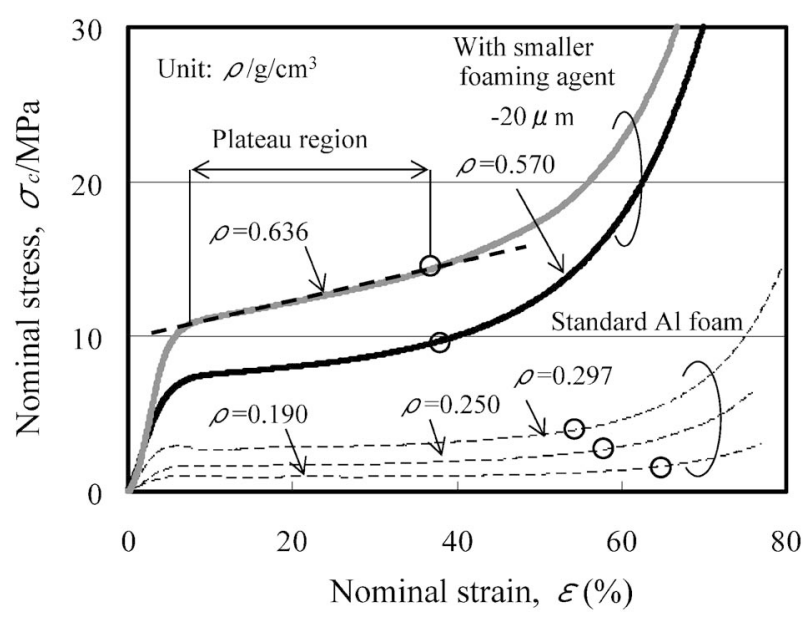

Fig. 18 Compressive stress-strain curves of several density Al foams with different sizes of foaming agent.

その分布幅は小さくなっている．発泡助剤粒径が小さくなる 々, 個々の解離水素ガス量が少なくなる一方, 比表面積が増 加するためにアルミニウム溶湯への投入直後の解離が速くな り，短時間に大部分のガスが発生すると考えられる．従っ て，発泡助剤投入直後の溶湯表面からのガスの散逸が増大 し，溶湯内部のガス圧が十分に上がらなかったことで比重が 大きく(気孔率が低い), 気孔径が小さくなったと思われる.

Fig. 18 に標準供試材と小粒径発泡材の圧縮応力ーひずみ曲 線を示す．3.1で定義したように，ほぼ一定の勾配で応力が 变化する部分をプラト一領域とすると，図中に一例(破線)を 示したように，一定勾配から外れる付近 (各曲線の○印)がプ ラトー領域の終点となる.すなわち小粒径発泡材では, 比重 の増加によって圧縮応力は上昇し，プラト一領域は短くなる ことがわかる。

Fig. 19 は，Fig. 15 に Fig. 18 の小粒径発泡材のプラトー 応力を追加したものである.クローズドセル構造のポーラス アルミニウムの塑性変形強度 (プラト一応力に相当)を表す式 として，セル構造を考慮した弾塑性力学的な考察から，ポー ラスアルミニウムの圧縮相対強度 $\left(\sigma_{\mathrm{ps}} / \sigma_{\mathrm{ys}}\right)$ がその相対密度 $\left(\rho / \rho_{\mathrm{s}}\right)$ の $3 / 2$ 乗に比例するとした次式が提案されている $\left.{ }^{14}\right)$.

$$
\sigma_{\mathrm{ps}} / \sigma_{\mathrm{ys}}=C\left(\rho / \rho_{\mathrm{s}}\right)^{3 / 2}
$$

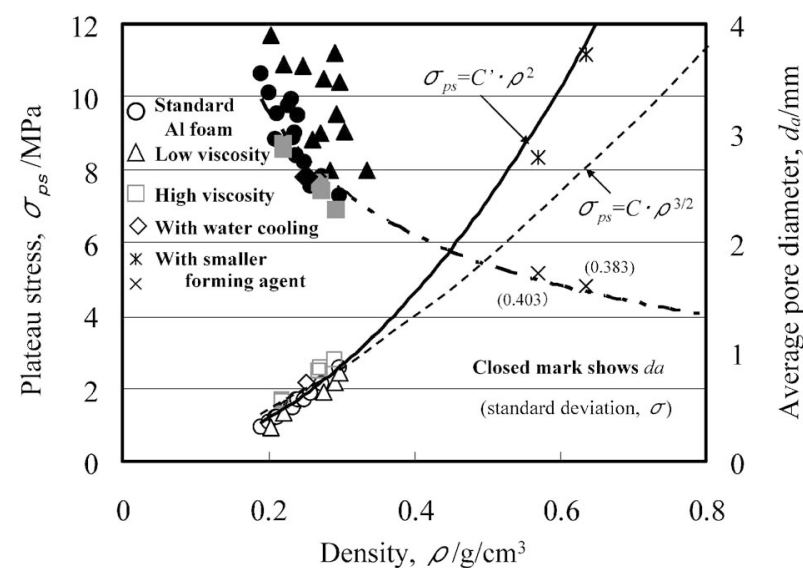

Fig. 19 Relation between density and plateau stress of $\mathrm{Al}$ foams.

ここで， $\sigma_{\mathrm{ps}}$ および $\rho$ はポーラスアルミニウムの塑性変形 強度 (プラト一応力に相当) 抢よび密度, $\sigma_{\mathrm{ys}}$ 抢よび $\rho_{\mathrm{s}}$ は緻密 なセル壁材での降伏応力および密度, $C$ はセル形態に関連し た定数である。

図中の破線は, 標準供給試験材を基にプラト一応力が比重 の $3 / 2$ 乗で増加するとした曲線であるが，小粒径発泡材の プラトー応力はこの曲線から大きく外れている. 一方実線 は, プラト一応力が比重の約 2 乗で増加するとした曲線で あり, 小粒径発泡材のプラトー応力はこの曲線に近くなって いる. Fig. 16 中の四角で示されたセル壁の形状を比較する と, 標準供試材は細長いが小粒径発泡材のセル壁は丸みを帯 びていることがわかる。セル壁が丸みを帯びたことによっ て, プラトー応力は比重の $3 / 2$ 乗より大きい約 2 乗で増加 したと思われる15).

\section{4. 結言}

（1）増粘剤 (Ca) 添加量が増すと気孔径が小さく均質にな るが，2.5 mass\%以上でほぼ一定となる.

(2) 増粘剤の添加量が多い試料ではプラトー領域の圧縮応 力が高くなり， 5.0 mass\%では生成化合物の増加と凝集によ って変形が脆性的になり，プラト一領域が長くなる.

（3）冷却速度の増大は粘性の増加々同様に気孔を均質小粒 径化する効果があり, 同比重のポーラスアルミニウムでもプ ラトー応力は向上する.

（4）小粒径の発泡助剤を用いると気孔径が小さくなるが， 同時にセル壁が厚くなり比重が大きくなる.

(5) 気孔サイズと比重が大きく変化したポーラスアルミニ ウムのプラトー応力は, 比重の約 2 乗で増加することが明 らかとなった。

なお, 本研究の一部は, 新エネルギー・産業技術総合開発 機構 $(\mathrm{NEDO})$ の委託研究として行われたものである.

\section{文献}

1) M. F. Ashby, A. G. Evans, N. A. Fleck, L. J. Gibson, J. W. 
Hutchinson and H. N. G. Wadley: Metal Foams, A Design Guide, (Butterworth-Heinemann, USA, 2000).

2) R. Neugebauer and T. Hipke: Porous Metals and Metal foaming Technology, (The Japan Inst. Metals, 2005) pp. 63-68.

3) G. Rausch and K. Stoubener: Porous Metals and Metal foaming Technology, (The Japan Inst. Metals, 2005) pp. 1-4.

4) S. Nishi, K. Makii, Y. Aruga, T. Hamada, J. Naito and T. Miyoshi: The Manufacturing Process and Mechanical Properties of Porous Aluminum, (R\&D Kobe Steel Eng. Reports, 54, 2004) 1, pp. 89-94.

5) S. Akiyama, H. Ueno, K. Imagawa, A. Kitahara, S. Nagata, K. Morimoto, T. Nishikawa and M. Itoh: European Patent Application EP 0210803 A1 (1986), Foamed Metal and Method of Producing Same, U.S. Patent 4713277 (1987).

6) H. Ueno and S. Akiyama: Foamed aluminum used Shirasu as blowing agent, (Industrial Research Institute, Kyushu) (Reprinted from the Reports of Government), 37(1986) pp.
$2355-2361$

7) H. Ueno and S. Akiyama: J. J ILM 37 (1987) 42-47.

8) C. C. Yang and H. Nakae: Japan Foundry Eng. Society 72(2000) 593-598.

9) T. Miyoshi, M. Itoh, S. Akiyama and A. Kitahara: Advanced Engineering Materials 2 (2000) 179-183.

10) T. Miyoshi and T. Hamada: Sokeizai, 47, No. 6(2006) 10-17.

11) T. Miyoshi: Cyuzokougaku, 74(2002) 835-839.

12) I. Jin, L. D. Kenny and H. Sang: Stabilized Metal Foam Body, U.S. Patent 5112 679(1992).

13) T. Miyoshi, S. Hara, T. Mukai and K. Higashi: Mater. Trans. JIM 42(2001) 2118-2123.

14) L. J. Gibson and M. F. Ashby: Cellular Solids, Structure and Properties, $2^{\text {nd }}$ ed., (Cambridge Univ. Press, Cambridge, UK, 1997).

15) A. E. Simone and L. J. Gibson: Acta mater. 46 (1998) 21392150 . 